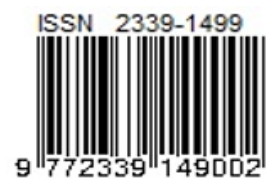

\title{
Model Perilaku Berbagi Pengetahuan antar IKM dalam Sebuah Sentra
}

\author{
Cindy Marika Amalia Wibowo ${ }^{1}$, Ceicalia Tesavrita ${ }^{2}$ \\ 1,2) Fakultas Teknologi Industri, Jurusan Teknik Industri, Universitas Katolik Parahyangan \\ Jl. Ciumbuleuit 94, Bandung 40141 \\ Email: cindymarika@unpar.ac.id, ceicalia@unpar.ac.id
}

\begin{abstract}
This research aims to map SME's behaviour in knowledge sharing in a SME's center. Knowledge sharing activity is one of key factor in knowledge management, where individual/group knowledge can be disseminated well and increase organization intellectual capital. Many research has identified variables that are affecting knowledge sharing activity, but the results cannot be generalized. This research uses literature study and interview to identify those variables in two SME's center in Java. The questionnaires then developed based on the 35 variables that are identified. Factor analysis is used to analyze the data and generate six factors that are affecting knowledge sharing activity in SME's center, such as job characteristic, technology, internal individual, environmental influence, reward system, and job security. The result of SEM show that technology, internal individual, and environmental influence has positive relationships toward knowledge sharing activity, while job characteristic and reward system has negative relationships toward knowledge sharing activity.
\end{abstract}

Keywords: knowledge management, knowledge sharing, factor analysis, SEM, SME's center

Abstrak

Penelitian ini bertujuan untuk memetakan perilaku IKM untuk berbagi pengetahuan di dalam sebuah sentra IKM. Aktivitas berbagi pengetahuan merupakan salah satu faktor kunci dalam pengelolaan pengetahuan, dimana pengetahuan yang ada dalam individu/kelompok dapat terdiseminasikan dengan baik dan menambah aset pengetahuan organisasi. Beberapa penelitian berhasil mengindentifikasi variabel-variabel yang berpengaruh pada aktivitas berbagi pengetahuan, namun hasilnya tidak dapat digeneralisasi. Dilakukan studi literatur dan wawancara untuk mengidentifikasi variabel-variabel tersebut pada dua buah sentra IKM di Jawa. Terdapat 35 variabel yang teridentifikasi dan dijadikan dasar untuk perancangan kuesioner. Data kemudian diolah dengan menggunakan analisis faktor dan terbentuk enam faktor yang berpengaruh terhadap aktivitas berbagi pengetahuan di sentra IKM, yaitu faktor karakteristik pekerjaan, teknologi, internal individu, pengaruh lingkungan, sistem penghargaan, dan job security. Hasil analisis SEM menunjukkan bahwa faktor teknologi, internal individu, dan pengaruh lingkungan memiliki hubungan positif terhadap aktivitas berbagi pengetahuan, sementara faktor karakteristik pekerjaan dan sistem penghargaan memiliki hubungan negatif terhadap aktivitas berbagi pengetahuan.

Kata kunci: pengelolaan pengetahuan, berbagi pengetahuan, analisis faktor, SEM, sentra IKM

\section{Pendahuluan}

Menurut data Bank Indonesia (2009) UMKM memiliki peran yang penting bagi negara Indonesia karena memberikan kontribusi yang besar pada PDB negara (58\%) dan juga menyerap tenaga kerja yang tidak sedikit. Tedjasuksmana (2014) menyatakan bahwa peran IKM dalam perekonomian Indonesia antara lain: (1) penyerapan tenaga kerja sebesar 99,45\%; (2) pengembangan kegiatan ekonomi lokal dan pemberdayaan masyarakat; (3) penciptaan pasar baru dan sumber inovasi dan (4) kontribusi dalam pendapatan devisa negara.

Walaupun IKM berperan penting dalam perekonomian negara, IKM memiliki permasalahan dalam menjaga keberlanjutan usahanya. Berdasarkan data GEM pada tahun 2012, tingkat keberlanjutan (sustainability) IKM di Indonesia hanyalah sekitar 2,4\% saja, jauh 
lebih kecil bila dibandingkan dengan negaranegara ASEAN lainnya. Faktor yang menyebabkan rendahnya keberlanjutan usaha tersebut adalah: (1) usaha tidak memberikan keuntungan yang cukup, (2) permasalahan keuangan, (3) kesempatan usaha lain, (4) tidak adanya daya saing dan berbagai alasan lainnya (Nawangpalupi et al., 2014).

Darcy et al. (2014) menyatakan bahwa salah satu cara untuk menjaga keberlanjutan usaha adalah melalui pengelolaan kapabilitas sumber daya manusianya, dimana pengelolaan pengetahuan (knowledge management) yang baik menjadi faktor kunci (Darcy et al., 2014; Zhang dan Jiang, 2015). Melalui pengelolaan pengetahuan yang baik, dan aktivitas berbagi pengetahuan yang efektif, maka proses pembelajaran dalan organisasi dapat dipercepat dan dapat meningkatkan performansi organisasi tersebut (Tesavrita dan Suryadi, 2016).

Knowledge sharing didefinisikan sebagai proses transfer dan diseminasi knowledge yang terjadi secara sukarela, dari satu individu ke individu lain, yang terjadi dalam satu organisasi (Bock et al., 2010). Proses diseminasi/sharing knowledge ini tidak terjadi secara spontan. Perumusan model knowledge sharing yang efektif pada sebuah sentra IKM harus didasarkan pada pemahaman yang baik akan faktor-faktor yang berpengaruh pada kesediaan individu untuk mendiseminasikan pengetahuan yang dimiliki.

Penelitian ini menghasilkan model knowledge sharing yang dapat digunakan untuk mengetahui perilaku berbagi pengetahuan antar IKM dalam sebuah sentra. Dengan adanya model knowledge sharing beserta hubungan antarfaktornya, dapat diketahui halhal apa saja yang perlu dilakukan untuk mendorong terjadinya aktivitas berbagi pengetahuan yang efektif. Adanya aktivitas berbagi pengetahuan yang efektif akan berdampak pada meningkatnya keberlanjutan usaha IKM dalam sebuah sentra.

\section{Identifikasi Variabel Knowledge Sharing}

Telah banyak penelitian yang mencoba mengidentifikasikan variabel-variabel yang berpengaruh pada aktivitas berbagi pengetahuan. Penelitian tersebut dilakukan pada objek dan konteks yang beragam sehingga model yang dihasilkan pun beragam dan tidak dapat digeneralisasikan. IKM yang tergabung dalam sebuah sentra memiliki karakteristik yang berbeda dengan organisasi pada umumnya, sehingga memerlukan pendekatan yang berbeda dalam memetakan perilaku aktivitas berbagi pengetahuannya (Eze et al., 2013).

Beberapa penelitian yang telah mengidentifikasikan variabel-variabel yang berpengaruh pada knowledge sharing antara lain:

1. Wang dan Noe (2010) melakukan review terhadap 76 jurnal yang dipublikasikan pada tahun 1999 sampai dengan 2008 dan mensintesakan bahwa faktor-faktor yang berpengaruh terhadap knowledge sharing (KS) dapat dikelompokkan menjadi faktor lingkungan (organisasi, karakteristik kelompok, dII), faktor individu (tingkat pendidikan, self-efficacy, dll) dan faktor motivasi (kepercayaan, biaya sosial, dll).

2. Noor et al. (2014) juga melakukan studi literatur dan mendapatkan bahwa faktor yang berpengaruh terhadap KS dapat dikelompokkan menjadi faktor organisasi, faktor individu, dan faktor teknologi.

3. Eze et al. (2013) menyatakan bahwa terdapat perbedaan karakteristik pada IKM jika dibandingkan dengan perusahaan/ organisasi yang besar. Hal ini akan berpengaruh terhadap perilaku IKM dalam mengelola dan membagikan pengetahuan. Dilakukan survey terhadap 680 IKM pada bidang manufaktur yang ada di Malaysia, untuk mencoba memetakan bagaimana perilaku IKM tersebut dalam membagikan pengetahuannya. Dalam mengembangkan modelnya, Eze et al. (2013) menggunakan pendekatan incentive theory dan theory of reasoned action dan melakukan pengujian kuantitatif untuk memvalidasi model. Dari hasil pengujian, didapatkan faktor yang berpengaruh pada intensi untuk melakukan knowledge sharing di IKM adalah sistem rewards, teknologi, kepemimpinan, formalisasi, dan kepercayaan.

4. Schauer et al. (2015) mengemukakan sebuah model konseptual tentang knowledge sharing yang dinamakan model ShaRInk. Model tersebut menyatakan bahwa terdapat empat faktor kunci yang berpengaruh terhadap perilaku individu untuk mau melakukan knowledge sharing, yaitu sharer, relasi (sharer-recipient), institusi, dan tipe pengetahuan. 
Berdasarkan penelitian-penelitian tersebut, teridentifikasi 35 variabel yang berpengaruh terhadap aktivitas berbagi pengetahuan (knowledge sharing) di sentra IKM, yang dapat dilihat pada Tabel 1. Dilakukan juga wawancara dan observasi pada dua sentra IKM yang ada di Jawa. Sentra IKM A merupakan sentra IKM penghasil susu sapi dan produk olahannya yang berada di Jawa Barat. IKM pada sentra ini bergabung dan dikelola oleh sebuah koperasi. Sentra IKM B merupakan sentra IKM batik yang ada di Surakarta, Jawa Tengah. IKM pada sentra ini bergabung dibawah sebuah forum yang berfungsi sebagai mediator kerja sama antara IKM dengan organisasi eksternal.

Wawancara dilakukan pada perwakilan dari koperasi, forum, dan juga beberapa pelaku IKM. Tujuan dari wawancara dan observasi ini adalah untuk memvalidasi variabel yang teridentifikasi dari studi literatur dan juga mengidentifikasikan variabel tambahan. Teridentifikasi 4 variabel tambahan dan 3 variabel yang dihilangkan karena tidak sesuai dengan konteks objek penelitian dan dapat dilihat pada Tabel 1.

Tabel 1. Variabel yang berpengaruh pada knowledge sharing

\begin{tabular}{|c|c|c|c|}
\hline No & Faktor & Variabel & Kode \\
\hline \multirow{6}{*}{1} & \multirow{6}{*}{$\begin{array}{l}\text { Karakteristik } \\
\text { Pekerjaan }\end{array}$} & $\begin{array}{l}\text { Tata urut } \\
\text { pekerjaan }\end{array}$ & KP1 \\
\hline & & Aturan kerja & KP2 \\
\hline & & Informasi kerja & KP3 \\
\hline & & $\begin{array}{l}\text { Kesempatan } \\
\text { inovasi }\end{array}$ & KP4 \\
\hline & & $\begin{array}{l}\text { Aktivitas } \\
\text { diseminasi }\end{array}$ & KP5 \\
\hline & & $\begin{array}{l}\text { Kebebasan } \\
\text { mengambil } \\
\text { keputusan }\end{array}$ & KP6 \\
\hline \multirow{3}{*}{2} & \multirow{3}{*}{ Teknologi } & $\begin{array}{l}\text { Teknologi } \\
\text { informasi }\end{array}$ & T1 \\
\hline & & $\begin{array}{l}\text { Kemampuan } \\
\text { menggunakan } \\
\text { teknologi }\end{array}$ & T2 \\
\hline & & Update teknologi & T3 \\
\hline \multirow{7}{*}{3} & \multirow{7}{*}{$\begin{array}{l}\text { Internal } \\
\text { Individu }\end{array}$} & Motivasi diri & II1 \\
\hline & & Kepuasan diri & II2 \\
\hline & & Perasaan penting & II3 \\
\hline & & Perasaan berguna & 114 \\
\hline & & Menepati janji & 115 \\
\hline & & Konsistensi & 116 \\
\hline & & $\begin{array}{l}\text { Attitude pada } \\
\text { kejujuran }\end{array}$ & 117 \\
\hline
\end{tabular}

Tabel 1. Variabel yang berpengaruh pada knowledge sharing (lanjutan)

\begin{tabular}{|c|c|c|c|}
\hline No & Faktor & Variabel & Kode \\
\hline \multirow{12}{*}{4} & \multirow{12}{*}{$\begin{array}{l}\text { Pengaruh } \\
\text { Lingkungan }\end{array}$} & Motivasi sosial & PL1 \\
\hline & & $\begin{array}{l}\text { Manfaat } \\
\text { bersama }\end{array}$ & PL2 \\
\hline & & $\begin{array}{l}\text { Pengakuan dari } \\
\text { rekan }\end{array}$ & PL3 \\
\hline & & $\begin{array}{l}\text { Dampak } \\
\text { pertemanan }\end{array}$ & PL4 \\
\hline & & $\begin{array}{l}\text { Kedekatan } \\
\text { sosial }\end{array}$ & PL5 \\
\hline & & $\begin{array}{l}\text { Dukungan } \\
\text { lingkungan }\end{array}$ & PL6 \\
\hline & & $\begin{array}{l}\text { Percaya akan } \\
\text { kejujuran rekan }\end{array}$ & PL7 \\
\hline & & Kerja sama & PL8 \\
\hline & & $\begin{array}{l}\text { Dorongan dari } \\
\text { lingkungan }\end{array}$ & PL9 \\
\hline & & $\begin{array}{l}\text { Ekspektasi } \\
\text { lingkungan }\end{array}$ & PL10 \\
\hline & & $\begin{array}{l}\text { Dorongan dari } \\
\text { atasan }\end{array}$ & PL11 \\
\hline & & $\begin{array}{l}\text { Supervisi } \\
\text { penyuluh }\end{array}$ & PL12 \\
\hline \multirow{5}{*}{5} & \multirow{5}{*}{$\begin{array}{l}\text { Sistem } \\
\text { Penghargaan }\end{array}$} & Reputasi & SP1 \\
\hline & & $\begin{array}{l}\text { Penghargaan } \\
\text { sosial }\end{array}$ & SP2 \\
\hline & & $\begin{array}{l}\text { Penghargaan } \\
\text { dari atasan }\end{array}$ & SP3 \\
\hline & & Insentif uang & SP4 \\
\hline & & $\begin{array}{l}\text { Penghargaan } \\
\text { dari rekan }\end{array}$ & SP5 \\
\hline \multirow[t]{2}{*}{6} & \multirow[t]{2}{*}{ Job Security } & $\begin{array}{l}\text { Keamanan kerja } \\
\text { dari } \\
\text { pengetahuan } \\
\text { baru }\end{array}$ & JS1 \\
\hline & & $\begin{array}{l}\text { Keamanan kerja } \\
\text { dari knowledge } \\
\text { sharing }\end{array}$ & JS2 \\
\hline
\end{tabular}

Selain mengidentifikasikan variabel-variabel yang berpengaruh pada knowledge sharing, dilakukan juga proses identifikasi variabelvariabel yang membentuk knowledge sharing melalui studi literatur. Variabel pembentuk knowledge sharing diperoleh dari hasil penelitian Eze et al. (2013) dan dapat dilihat pada Tabel 2 .

Tabel 2. Variabel pembentuk knowledge sharing

\begin{tabular}{|l|c|}
\hline \multicolumn{1}{|c|}{ Variabel } & Kode \\
\hline Keinginan berbagi pengalaman pribadi & KS1 \\
\hline Keinginan berbagi ilmu dari luar organisasi & KS2 \\
\hline $\begin{array}{l}\text { Keinginan berbagi keahlian pada proses } \\
\text { kerja }\end{array}$ & KS3 \\
\hline \multicolumn{2}{|c}{ (lanjut) } \\
\end{tabular}


Tabel 2. Variabel pembentuk knowledge sharing (lanjutan)

\begin{tabular}{|l|c|}
\hline \multicolumn{1}{|c|}{ Variabel } & Kode \\
\hline $\begin{array}{l}\text { Keinginan berbagi pengetahuan dari } \\
\text { pelatihan }\end{array}$ & KS4 \\
\hline Keinginan berbagi ide dan pikiran & KS5 \\
\hline Rencana untuk berbagi pengetahuan & KS6 \\
\hline $\begin{array}{l}\text { Keinginan mencoba berbagi pengalaman } \\
\text { dan pengetahuan }\end{array}$ & KS7 \\
\hline
\end{tabular}

Seluruh variabel yang teridentifikasi digunakan sebagai butir pertanyaan dalam sebuah kuesioner yang disebarkan kepada 275 responden yang berasal dari sentra IKM A dan IKM B.

\section{Analisis Structural Equation Modelling}

Structural Equation Modelling (SEM) merupakan bagian dari model statistik yang bertujuan untuk menjelaskan hubungan antarvariabel. SEM memeriksa struktur hubungan melalui berbagai persamaan, serupa dengan rangkaian persamaan multiple regression. Persamaan tersebut menggambarkan seluruh hubungan antar konstruk (variabel dependen dan independen) yang dilibatkan dalam analisis. Konstruk yang tidak dapat diobservasi direpresentasikan oleh beberapa variabel (Hair et al., 2010). Pada penelitian ini, konstruk yang tidak dapat diobservasi disebut dengan variabel laten dan variabel yang merepresentasikannya disebut dengan variabel manifes.

Model SEM dibedakan berdasarkan 3 karakteristik (Hair et al., 2010):
1. Estimasi
berbagai
hubungan

ketergantungan yang saling terkait.

2. Kemampuan untuk merepresentasikan konsep yang tidak teramati dalam hubungan dan memperhitungkan kesalahan dalam proses estimasi.

3. Mendefinisikan model untuk menjelaskan keseluruhan hubungan.

Perbedaan utama antara SEM dengan teknik multivariat lainnya adalah penggunaan hubungan terpisah untuk masing-masing set variabel dependen. Sederhananya, SEM mengestimasikan rangkaian persamaan multiple regression yang terpisah (namun saling bergantung) secara simultan dengan menentukan model struktural yang digunakan oleh program statistik (Hair et al., 2010).

Untuk dapat membentuk model berbagi pengetahuan antar IKM dalam sebuah sentra, digunakan SEM dengan metode estimasi maximum likelihood (ML) untuk menjelaskan hubungan antara keenam faktor terhadap knowledge sharing menggunakan software AMOS. Model awal SEM yang digunakan dalam penelitian ditunjukkan pada Gambar 1.

Menurut Santoso (2011), pengujian model SEM dapat dibagi ke dalam 2 bagian besar, yaitu uji validitas measurement model dan structural model. Uji validitas measurement model dilakukan terhadap masing-masing variabel laten beserta variabel manifesnya dan bertujuan untuk mengetahui seberapa tepat variabel manifes dapat menjelaskan variabel laten. Uji validitas structural model dilakukan terhadap keseluruhan model penelitian yang bertujuan untuk mengetahui hubungan antarvariabel.

Tabel 3. Variabel manifes dan nilai factor loading

\begin{tabular}{|lll|r|}
\hline & & & Estimate \\
\hline KP6 & $<---$ & Karakteristik_Pekerjaan & 1 \\
KP5 & $<---$ & Karakteristik_Pekerjaan & 0,652 \\
KP4 & $<---$ & Karakteristik_Pekerjaan & 4,251 \\
KP2 & $<---$ & Karakteristik_Pekerjaan & 1,809 \\
KP1 & $<---$ & Karakteristik_Pekerjaan & 1,084 \\
\hline T3 & $<---$ & Teknologi & 1 \\
T2 & $<---$ & Teknologi & 0,917 \\
T1 & $<---$ & Teknologi & 0,614 \\
\hline II7 & $<---$ & Internal_Individu & 1 \\
II6 & $<---$ & Internal_Individu & 0,543 \\
II1 & $<---$ & Internal_Individu & 1,339 \\
\hline PL12 & $<---$ & Pengaruh_Lingkungan & 1 \\
PL6 & $<---$ & Pengaruh_Lingkungan & 0,635 \\
PL1 & $<---$ & Pengaruh_Lingkungan & 0,835 \\
\hline SP5 & $<---$ & Sistem_Penghargaan & 1 \\
SP4 & $<---$ & Sistem_Penghargaan & 1,522 \\
SP3 & $<---$ & Sistem_Penghargaan & $-0,669$ \\
SP2 & $<---$ & Sistem_Penghargaan & 1,762 \\
SP1 & $<---$ & Sistem_Penghargaan & 4,022 \\
\hline KS1 & $<---$ & Knowledge_Sharing & 1 \\
KS2 & $<---$ & Knowledge_Sharing & $-4,605$ \\
KS3 & $<---$ & Knowledge_Sharing & $-3,303$ \\
\hline KS4 & $<---$ & Knowledge_Sharing & $-7,355$ \\
KS5 & $<---$ & Knowledge_Sharing & $-9,497$ \\
KS6 & $<---$ & Knowledge_Sharing & $-4,827$ \\
KS7 & $<---$ & Knowledge_Sharing & 1,344 \\
\hline
\end{tabular}

Dalam pengujian validitas measurement model, variabel manifes yang memiliki nilai absolut factor loading (estimate) terhadap variabel laten kurang dari nilai standar 0,5 akan dihilangkan karena variabel manifes tersebut tidak dapat menjelaskan variabel laten dengan tepat. 


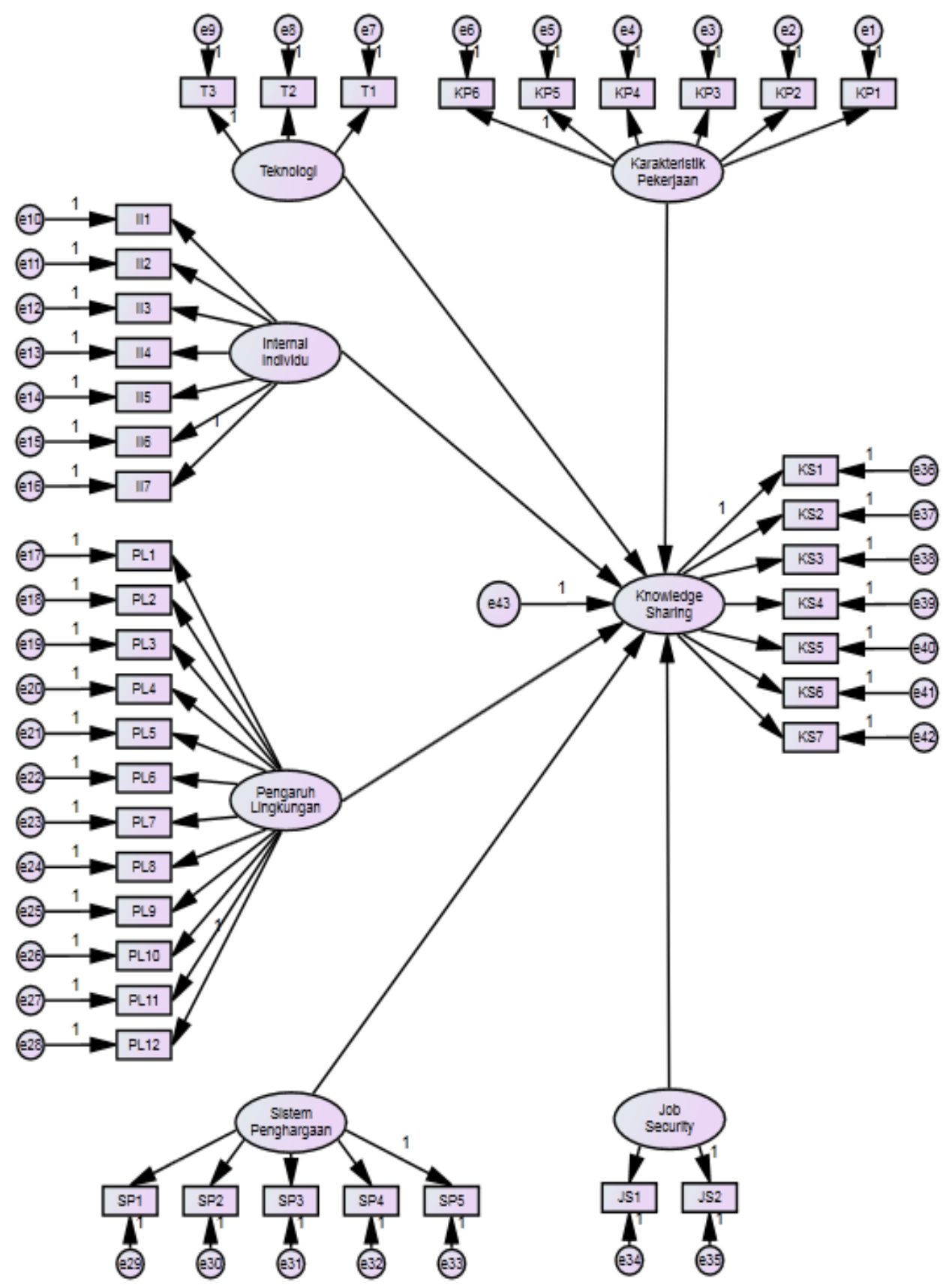

Gambar 1. Model awal SEM

Khusus variabel laten job security tidak dilakukan uji validitas measurement model karena hanya memiliki 2 buah variabel manifes. Rekapitulasi variabel manifes yang lolos uji measurement model beserta nilai factor loading-nya dapat dilihat pada Tabel 3.

Pada pengujian validitas measurement model dilakukan pengujian model fit berdasarkan 3 jenis parameter, yaitu nilai CMIN, RMR, dan GFI. Menurut Santoso (2011), model dapat dinyatakan fit dengan data yang ada apabila nilai CMIN default mode/ berada di antara nilai CMIN saturated dan independence model, RMR default model mendekati 0, dan GFI default model mendekati 1 . Terbatasnya jumlah variabel manifes pada variabel laten job security mengakibatkan variabel laten job security tidak dapat dilakukan uji model fit.

Hasil pengujian menunjukkan bahwa model masing-masing variabel laten dapat dinyatakan fit dengan data yang ada (lihat Tabel 4). 
Tabel 4. Nilai-nilai parameter pengujian model fit

\begin{tabular}{|c|c|c|c|}
\hline \multicolumn{4}{|c|}{ Karakteristik Pekerjaan } \\
\hline Model & CMIN & RMR & GFI \\
\hline Default model & 19,569 & 0,035 & 0,972 \\
\hline Saturated model & 0 & 0 & 1 \\
\hline Independence model & 150,87 & 0,117 & 0,82 \\
\hline \multicolumn{4}{|l|}{ Teknologi } \\
\hline Model & CMIN & RMR & GFI \\
\hline Default model & 0 & 0 & 1 \\
\hline Saturated model & 0 & 0 & 1 \\
\hline Independence model & 64,522 & 0,088 & 0,862 \\
\hline \multicolumn{4}{|l|}{ Internal Individu } \\
\hline Model & CMIN & RMR & GFI \\
\hline Default model & 0 & 0 & 1 \\
\hline Saturated model & 0 & 0 & 1 \\
\hline Independence model & 141,69 & 0,237 & 0,753 \\
\hline \multicolumn{4}{|l|}{ Pengaruh Lingkungan } \\
\hline Model & CMIN & RMR & GFI \\
\hline Default model & 0 & 0 & 1 \\
\hline Saturated model & 0 & 0 & 1 \\
\hline Independence model & 498,8 & 0,309 & 0,498 \\
\hline \multicolumn{4}{|l|}{ Sistem Penghargaan } \\
\hline Model & CMIN & RMR & GFI \\
\hline Default model & 197,99 & 0,162 & 0,854 \\
\hline Saturated model & 0 & 0 & 1 \\
\hline Independence model & 542,14 & 0,241 & 0,647 \\
\hline \multicolumn{4}{|l|}{ Knowledge Sharing } \\
\hline Model & CMIN & RMR & GFI \\
\hline Default model & 84,924 & 0,045 & 0,923 \\
\hline Saturated model & 0 & 0 & 1 \\
\hline Independence model & 154,74 & 0,073 & 0,864 \\
\hline
\end{tabular}

Selanjutnya dilakukan uji validitas structural model terhadap model keseluruhan. Menurut Santoso (2011), pengujian ini meliputi 2 bagian utama, yaitu pengujian structural parameter estimates dan overall model fit. Dalam pengujian structural parameter estimates, hubungan yang memiliki nilai $p$-value lebih besar dari nilai alpha sebesar 0,05 akan dihilangkan karena berarti hubungan tersebut lemah. Dari seluruh hubungan yang terdapat pada model keseluruhan, hubungan antara variabel laten job security dengan knowledge sharing lemah sehingga harus dihilangkan. Kemudian dilakukan pengujian kembali dan hasil pengujian menunjukkan bahwa hubungan antara KS7 dengan KS lemah sehingga harus dihilangkan. Model kemudian diuji kembali dan hasil pengujian ketiga menyatakan bahwa seluruh hubungan lolos uji. Hasil pengujian ketiga ditunjukkan melalui Tabel 5.
Tabel 5. Hasil pengujian structural parameter estimates

\begin{tabular}{|c|c|c|c|}
\hline & & & $P$ \\
\hline $\begin{array}{l}\text { Knowledge_ } \\
\text { Sharing }\end{array}$ & $<--$ & $\begin{array}{l}\text { Karakteristik_ } \\
\text { Pekerjaan }\end{array}$ & $\star \star \star *$ \\
\hline $\begin{array}{l}\text { Knowledge } \\
\text { Sharing }\end{array}$ & $<---$ & Teknologi & $* * *$ \\
\hline $\begin{array}{l}\text { Knowledge_ } \\
\text { Sharing }\end{array}$ & $<--$ & $\begin{array}{l}\text { Internal_- } \\
\text { Individu }\end{array}$ & 0,018 \\
\hline $\begin{array}{l}\text { Knowledge_ } \\
\text { Sharing }\end{array}$ & $<--$ & $\begin{array}{l}\text { Pengaruh_} \\
\text { Lingkungan }\end{array}$ & $\star \star \star \star$ \\
\hline $\begin{array}{l}\text { Knowledge_ } \\
\text { Sharing }\end{array}$ & $<---$ & $\begin{array}{l}\text { Sistem_- } \\
\text { Penghargaan }\end{array}$ & 0,006 \\
\hline KP6 & $<--$ & $\begin{array}{l}\text { Karakteristik_ } \\
\text { Pekerjaan }\end{array}$ & \\
\hline KP5 & $<--$ & $\begin{array}{l}\text { Karakteristik_ } \\
\text { Pekerjaan }\end{array}$ & 0,011 \\
\hline KP4 & $<---$ & $\begin{array}{l}\text { Karakteristik_ } \\
\text { Pekerjaan }\end{array}$ & $\star \star \star \star$ \\
\hline KP2 & $<--$ & $\begin{array}{l}\text { Karakteristik_ } \\
\text { Pekerjaan }\end{array}$ & $\star \star \star \star$ \\
\hline KP1 & $<---$ & $\begin{array}{l}\text { Karakteristik_ } \\
\text { Pekerjaan }\end{array}$ & $\star \star \star *$ \\
\hline T3 & $<---$ & Teknologi & \\
\hline T2 & $<---$ & Teknologi & 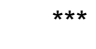 \\
\hline $\mathrm{T} 1$ & $<---$ & Teknologi & $\star \star \star *$ \\
\hline 117 & $<--$ & $\begin{array}{l}\text { Internal__ } \\
\text { Individu }\end{array}$ & \\
\hline 116 & $<--$ & $\begin{array}{l}\text { Internal__ } \\
\text { Individu }\end{array}$ & 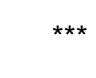 \\
\hline II1 & $<--$ & $\begin{array}{l}\text { Internal_- } \\
\text { Individu }\end{array}$ & $\star \star \star *$ \\
\hline PL12 & $<---$ & $\begin{array}{l}\text { Pengaruh_- } \\
\text { Lingkungan }\end{array}$ & \\
\hline PL6 & $<---$ & $\begin{array}{l}\text { Pengaruh_- } \\
\text { Lingkungan }\end{array}$ & $\star \star \star \star$ \\
\hline PL1 & $<---$ & $\begin{array}{l}\text { Pengaruh_} \\
\text { Lingkungan }\end{array}$ & $\star \star \star *$ \\
\hline KS1 & $<---$ & $\begin{array}{l}\text { Knowledge_ } \\
\text { Sharing }\end{array}$ & \\
\hline KS2 & $<--$ & $\begin{array}{l}\text { Knowledge } \\
\text { Sharing }\end{array}$ & 0,006 \\
\hline KS3 & $<---$ & $\begin{array}{l}\text { Knowledge } \\
\text { Sharing }\end{array}$ & $\star \star * *$ \\
\hline KS4 & $<---$ & $\begin{array}{l}\text { Knowledge_ } \\
\text { Sharing }\end{array}$ & 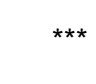 \\
\hline KS5 & $<--$ & $\begin{array}{l}\text { Knowledge_ } \\
\text { Sharing }\end{array}$ & $\star \star \star *$ \\
\hline KS6 & $<---$ & $\begin{array}{l}\text { Knowledge_ } \\
\text { Sharing }\end{array}$ & $\star \star \star \star$ \\
\hline SP5 & $<--$ & $\begin{array}{l}\text { Sistem_- } \\
\text { Penghargaan }\end{array}$ & \\
\hline SP4 & $<---$ & $\begin{array}{l}\text { Sistem_- } \\
\text { Penghargaan }\end{array}$ & 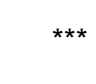 \\
\hline SP3 & $<---$ & $\begin{array}{l}\text { Sistem_- } \\
\text { Penghargaan }\end{array}$ & 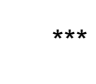 \\
\hline SP2 & $<--$ & $\begin{array}{l}\text { Sistem_- } \\
\text { Penghargaan }\end{array}$ & $\star \star \star *$ \\
\hline SP1 & $<---$ & $\begin{array}{l}\text { Sistem_- } \\
\text { Penghargaan }\end{array}$ & 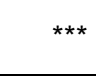 \\
\hline
\end{tabular}


Dalam pengujian overall model fit, parameter dan pengambilan keputusan sama dengan pengujian model fit untuk masingmasing variabel laten. Hasil pengujian menunjukkan bahwa model keseluruhan dinyatakan fit dengan data yang ada. Nilai-nilai parameter pengujian model fit untuk model keseluruhan dapat dilihat pada Tabel 6 .

Tabel 6. Nilai-nilai parameter pengujian model fit keseluruhan

\begin{tabular}{|l|rrr|}
\hline Model & CMIN & RMR & GFI \\
\hline Default model & 3051,5 & 0,18 & 0,526 \\
Saturated model & 0 & 0 & 1 \\
Independence model & 4460,5 & 0,195 & 0,375 \\
\hline
\end{tabular}

Berdasarkan seluruh pengujian yang telah dilakukan, maka diperoleh model akhir SEM yang dapat dilihat pada Gambar 2. Model akhir penelitian kemudian divisualisasikan dengan lebih sederhana melalui Gambar 3.

\section{Pembahasan}

Hasil pengolahan data menunjukkan bahwa terdapat beberapa hubungan antara variabel manifes dengan variabel laten yang dihilangkan karena variabel manifes tersebut tidak dapat menjelaskan variabel laten dengan tepat. Hubungan-hubungan tersebut antara lain: (1) hubungan antara informasi kerja dengan karakteristik pekerjaan, (2) hubungan antara kepuasan diri, perasaan penting, perasaan berguna, dan menepati janji dengan internal individu, (3) hubungan antara manfaat bersama, pengakuan dari rekan, dampak pertemanan, kedekatan sosial, percaya akan kejujuran rekan, kerja sama, dorongan dari lingkungan, ekspektasi lingkungan, dan dorongan dari atasan dengan pengaruh lingkungan, serta (4) hubungan antara keinginan mencoba berbagi pengalaman dan pengetahuan dengan knowledge sharing.

Model penelitian akhir menunjukkan bahwa faktor-faktor yang yang berpengaruh terhadap aktivitas berbagi pengetahuan adalah karakteristik pekerjaan, teknologi, internal individu, pengaruh lingkungan, dan sistem penghargaan.

Faktor teknologi memiliki hubungan positif sebesar 0,65 terhadap aktivitas berbagi pengetahuan. Faktor teknologi terkait dengan teknologi informasi untuk berbagi pengetahuan, kemampuan koperasi menggunakan teknologi untuk membantu peternak berbagi pengetahuan, dan keaktifan koperasi untuk memperbaharui kegiatan dari teknologi informasi yang digunakan. Dengan nilai hubungan yang cukup besar, peningkatan pada faktor teknologi akan berdampak cukup besar pula terhadap peningkatan aktivitas berbagi pengetahuan.

Faktor internal individu memiliki hubungan positif sebesar 0,16 terhadap aktivitas berbagi pengetahuan. Faktor internal individu terkait dengan keuntungan berbagi pengetahuan yang dapat memotivasi diri peternak, konsistensi peternak dalam melakukan pekerjaan, dan kejujuran dalam berhadapan dengan peternak lain.

Faktor pengaruh lingkungan memiliki hubungan positif sebesar 0,47 terhadap aktivitas berbagi pengetahuan. Faktor pengaruh lingkungan terkait dengan apresiasi dari pihak koperasi setelah peternak berbagi pengetahuan, dukungan lingkungan peternakan untuk berbagi pengetahuan, dan supervisi penyuluh mengenai tugas-tugas peternak.

Faktor teknologi dan pengaruh lingkungan memiliki hubungan positif yang cukup besar terhadap aktivitas berbagi pengetahuan.

Oleh karena itu, dengan menyediakan teknologi informasi yang memadai dan menciptakan lingkungan yang suportif, maka aktivitas berbagi pengetahuan pun dapat meningkat. Salah satu hal yang dapat dilakukan adalah mengadakan forum rutin yang membahas mengenai aktivitas berbagi pengetahuan yang terjadi di dalam sentra. Apabila memungkinkan, forum dapat dilakukan melalui aplikasi pesan yang memanfaatkan teknologi dan memudahkan antaranggota koperasi untuk saling berkomunikasi. Melalui forum tersebut, anggota koperasi dapat saling berbagi pengetahuan, serta dapat secara terbuka memberikan apresiasi dan saling mendukung satu sama lain. 


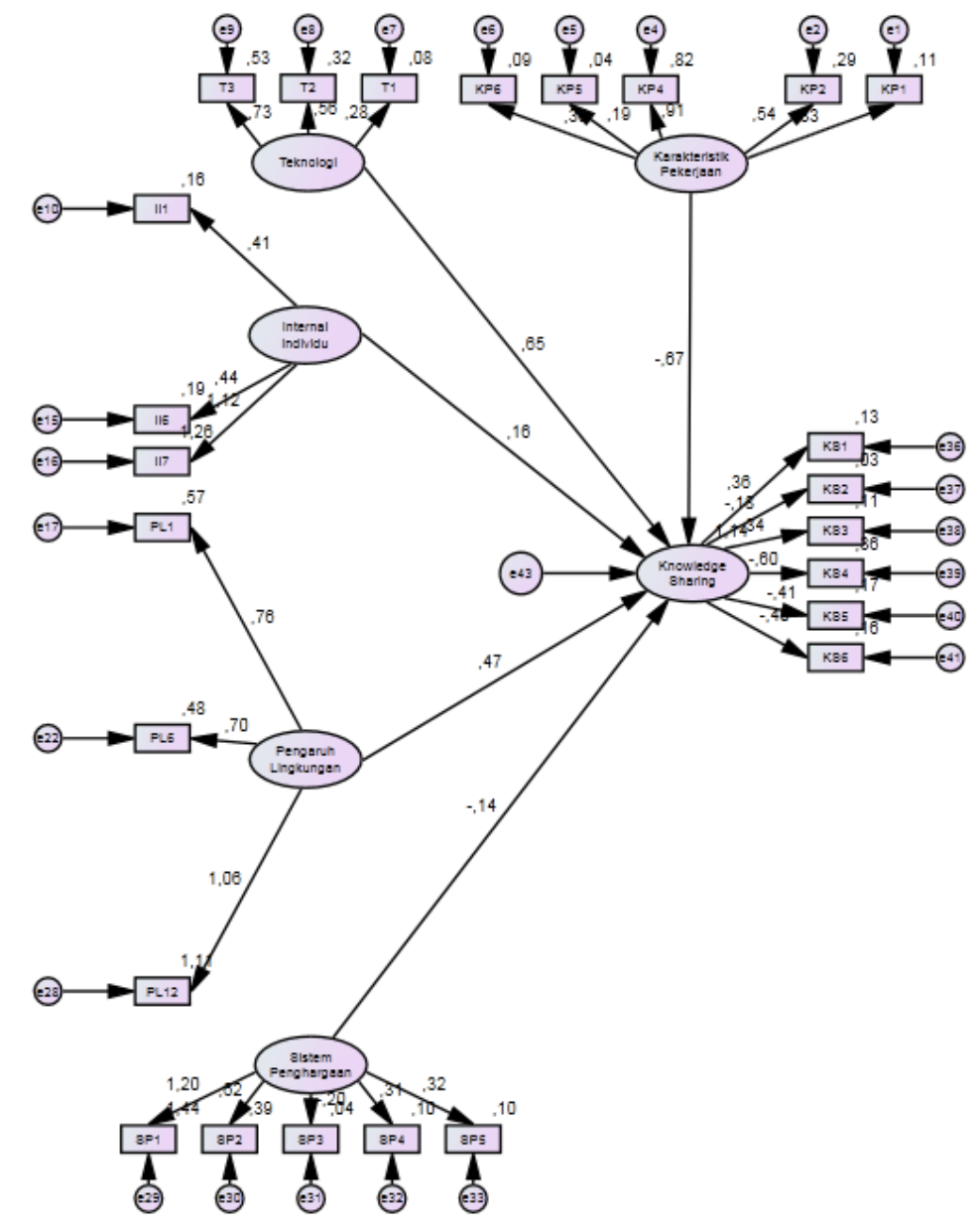

Gambar 2. Model akhir SEM

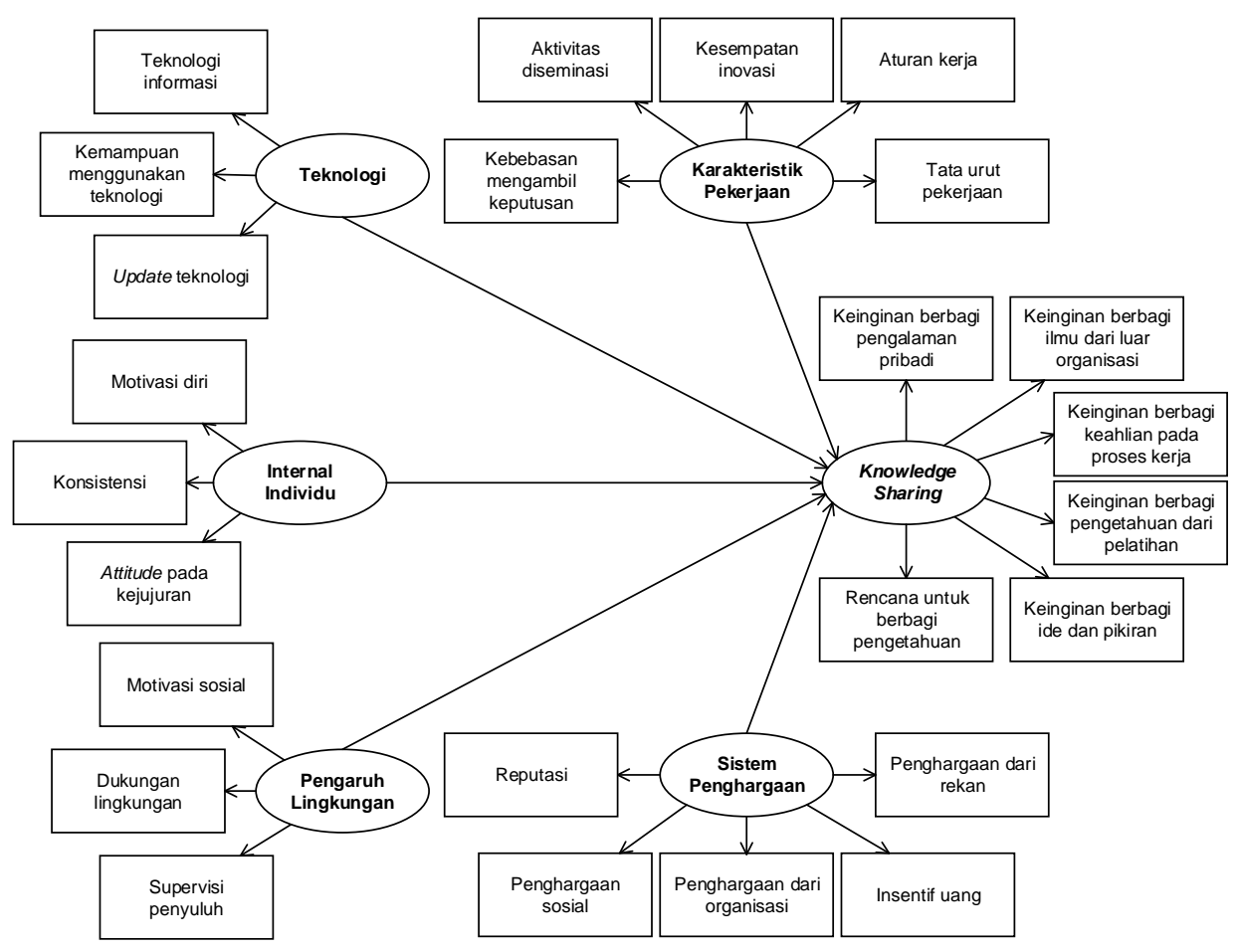

Gambar 3. Model akhir penelitian 
Faktor karakteristik pekerjaan memiliki hubungan negatif sebesar 0,67 terhadap aktivitas berbagi pengetahuan. Faktor karakteristik pekerjaan terkait dengan tata urut pekerjaan dari koperasi, aturan mengenai pekerjaan peternak, kesempatan untuk bereksperimen dengan ide-ide inovatif, kegiatan bersama untuk berbagi pengetahuan, dan kebebasan mengambil keputusan terkait dengan pekerjaan.

Faktor sistem penghargaan memiliki hubungan negatif sebesar 0,14 terhadap aktivitas berbagi pengetahuan. Faktor sistem penghargaan terkait dengan reputasi baik yang diperoleh setelah berbagi pengetahuan, hubungan timbal balik dengan peternak yang memperoleh pengetahuan, penghargaan dari pihak koperasi setelah berbagi pengetahuan, insentif yang diperoleh setelah berbagi pengetahuan, dan penghargaan dari rekan peternak lainnya setelah berbagi pengetahuan.

Faktor karakteristik pekerjaan memiliki hubungan negatif yang cukup besar terhadap aktivitas berbagi pengetahuan. $\mathrm{Hal}$ ini menunjukkan bahwa adanya aturan yang diberlakukan dalam koperasi cenderung memunculkan keengganan peternak untuk melakukan aktivitas berbagi pengetahuan. Oleh karena itu, sebaiknya sebisa mungkin peternak diberikan keleluasaan dalam melakukan pekerjaannya selama tidak berdampak pada menurunnya produktivitas dan kualitas pekerjaan peternak tersebut. Hal ini diharapkan dapat lebih mendorong peternak untuk terlibat aktif dalam aktivitas berbagi pengetahuan.

Faktor job security tidak lagi terdapat pada model penelitian akhir dan berarti bahwa faktor tersebut tidak berpengaruh terhadap aktivitas berbagi pengetahuan. Faktor job security sendiri dalam penelitian ini diwakili oleh 2 buah variabel, yaitu keamanan kerja dari pengetahuan baru dan keamanan kerja dari knowledge sharing. Adanya pengetahuan baru rupanya tidak berdampak pada bertambahnya rasa aman yang dimiliki oleh IKM akan keberlanjutan usahanya. Pengetahuan baru yang dapat diperoleh melalui aktivitas berbagi pengetahuan nyatanya tidak dapat memotivasi IKM untuk melakukan aktivitas tersebut. Di lain sisi, aktivitas berbagi pengetahuan juga tidak dipandang sebagai ancaman atas keberlanjutan usaha dari sebuah IKM. Hal ini menunjukkan bahwa walaupun manfaat dari aktivitas berbagi pengetahuan berupa pengetahuan baru dipandang tidak berdampak pada rasa aman yang dimiliki oleh IKM akan keberlanjutan usahanya, namun IKM juga tidak memandang bahwa aktivitas berbagi pengetahuan akan berdampak negatif terhadap keberlanjutan usahanya.

Bila dibandingkan dengan model-model penelitian sebelumnya, model aktivitas berbagi pengetahuan yang terbentuk memiliki faktor yang sedikit berbeda. Wang and Noe (2010), Noor et al (2014), dan Schauer et al (2015) merupakan penelitian studi literatur, dimana kerangka yang terbentuk merupakan model konseptual yang belum teruji secara empiris. Ketiga penelitian ini dijadikan dasar dalam pengembangan model aktivitas berbagi pengetahuan pada penelitian ini.

Eze et al (2013) mengembangkan model intensi untuk berbagi pengetahuan dan dilakukan pengujian secara empiris. Dalam model Eze et al (2013), faktor yang berpengaruh terhadap intensi berbagi pengetahuan adalah kepercayaan, formalisasi, teknologi pengetahuan, kepemimpinan, sistem penghargaan dan motivasi. Model Eze et al (2013) ini belum memperhitungkan pengaruh dari lingkungan sosial pada perilaku individu untuk berbagi pengetahuan. Pentingnya faktor relasi/hubungan antara individu dengan lingkungannya dikemukakan oleh Schauer et al (2015), dan pada penelitian ini juga ditemukan pengaruh yang signifikan pada aktivitas berbagi pengetahuan.

\section{Simpulan}

1. Berdasarkan pengolahan dengan menggunakan SEM, diketahui bahwa terdapat 5 faktor yang berpengaruh terhadap aktivitas berbagi pengetahuan, yaitu karakteristik pekerjaan, teknologi, internal individu, pengaruh lingkungan, dan sistem penghargaan.

2. Terdapat 3 buah faktor yang memiliki hubungan positif terhadap aktivitas berbagi pengetahuan, yaitu faktor teknologi, internal individu, dan pengaruh lingkungan. Artinya, peningkatan ketiga faktor tersebut akan berdampak pada peningkatan aktivitas berbagi pengetahuan.

3. Terdapat 2 buah faktor yang memiliki hubungan negatif terhadap aktivitas berbagi pengetahuan, yaitu faktor karakteristik pekerjaan dan sistem penghargaan. Artinya, peningkatan kedua faktor tersebut justru 
akan berdampak pada penurunan aktivitas berbagi pengetahuan.

4. Terdapat 1 buah faktor yang dihilangkan dari model knowledge sharing karena memiliki hubungan yang lemah dengan aktivitas berbagi pengetahuan, yaitu faktor job security.

\section{Daftar Pustaka}

Bank Indonesia (2009). Kajian mengenai Rumusan Standar Minimum Laporan Keuangan dan Business Plan untuk UMKM: Persiapan Bank Indonesia dalam Menghadapi Masyarakat Ekonomi ASEAN 2015. Direktorat Kredit BPR dan UMKM Bank Indonesia. Jakarta.

Bock G-W, Lee J Y, Lee, J. (2010). Cross Cultural Study on Behavioral Intention Formation in Knowlede Sharing. Asia Pasific Journal of Information System, Vol. 20 No 3, 01-32.

Darcy, Colette., Hill, Jimmy., McCabe, TJ., McGovern, Philip (2014). A Consideration of Organizational Sustainability in the SME Context. European Journal of Training and Development, Vol. 38 Iss 5, 398 - 414.

Eze U.C., Goh G.G.G, Goh C.Y., dan Tan T.L. (2013). Perspective of SME's on Knowledge Sharing. Emerald Insight, 110, 611-631.

Hair Jr., J. F., William C. B., Barry J. B., dan Rolph E. A. (2010). Multivariate Data Analysis, $7^{\text {th }}$ ed. New Jersey: Pearson Prentice Hall.

Nawangpalupi, C.B., Pawitan, G., Gunawan, A., Widyarini, M., Iskandarsjah, T. (2014). Global Entrepreneurship Monitor 2013 Indonesia Report. Bandung: Universitas Katolik Parahyangan.

Noor, Ammar Dheyaa., Hashim, Hayder Salah., Ali, Norashikin (2014). Factors Influencing Knowledge Sharing in Organizations: $A$ Literature Review. International Journal of Science and Research (IJSR). ISSN (Online): 2319-7064, Vol. 3 Iss 9.
Santoso, Singgih (2011). Structural Equation Modeling (Konsep dan Aplikasi dengan AMOS 18). Jakarta: PT Elex Media Komputindo.

Schauer, Alexander., Vasconcelos, Ana Cristina., Sen, Barbara (2015). The ShaRInK framework: A Holistic Perspective on Key Categories of Influences Shaping Individual Perceptions of Knowledge Sharing. Journal of Knowledge Management, Vol. 19 Iss 4, 770 - 790.

Tesavrita, C., dan Suryadi, K. (2016). Organization Learning through Effective Knowledge Sharing in SME's: A Conceptual Model. IEEE International Conference on Management of Innovation and Technology (ICMIT), $203-207$.

Wang, Sheng., dan Noe., Raymond A. (2010). Knowledge Sharing: A Review and Directions for Future Research. Human Resource Management Review 20, 115131.

Zhang, Xiao. dan Jiang, Jane Yan. (2015). With Whom Shall I Share My Knowledge? A Recipient Perspective of Knowledge Sharing. Journal of Knowledge Management, Vol. 19 Iss 2, 277 - 295. 